\title{
Microorganisms in the Zone of Submarine Volcanic Eruptions at 535-513 Ma
}

\author{
Petr N. Kolosov, Lena S. Sofroneeva \\ Diamond and Precious Metals Geology Institute, SB RAS, Yakutsk, Russia \\ Email: p kolosov@diamond.ysn.ru
}

Received 25 May 2014; revised 29 June 2014; accepted 24 July 2014

Copyright (C) 2014 by authors and Scientific Research Publishing Inc.

This work is licensed under the Creative Commons Attribution International License (CC BY). http://creativecommons.org/licenses/by/4.0/

cc) (i) Open Access

\begin{abstract}
New anatomical features revealed in some Early Cambrian calcareous microfossils suggest comparison with Rhodophyta (red algae), which makes it possible to define their taxonomic position. A taxonomically rich Early Cambrian paleobiocoenosis has been discovered in northern Tien Shan, which exemplifies the existence on earth at 535-513 Ma (million years) of morphologically complex fungiform microorganisms and red algae in a shallow-water biotope where environmental conditions favorable for life were created as a result of submarine volcanic eruptions.
\end{abstract}

\section{Keywords}

Calcareous Microfossil, Tetraspore, Tetrasporangium, Rhodophyta, Cambrian, Volcanicity, Paleobiocoenosis, Tien Shan

\section{Introduction}

Calcareous microfossils found in Early Paleozoic (541-416 Ma) sedimentary strata are regarded by most researchers as fossil remains of cyanobacteria and algae. These organisms deserve more attention than has been paid to them so far. As mentioned by B.I. Chuvashov [1], calcareous algae are most frequently found in the sections of different-aged sedimentary rocks. They are helpful in interpreting depositional environments.

It is only the external appearance that is preserved in cyanobacteria, bacteria and algae microfossils. Their biological interpretation and definition of their taxonomic position are very difficult because representatives of different series of lower water plants growing in similar environments may have close morphology.

Except for some taxons (e.g. Epiphyton Bornemann), Early Cambrian (541-513 Ma) deposits contain very rare well-preserved calcareous microfossils for which it is possible to determine their taxonomic position and thus to obtain information on the early evolutionary stages of microorganisms represented by prokaryotes (cyanobacteria and bacteria) and eukaryotes (algae). 
The goal of the researches conducted by authors was biologic interpretation of well preserved Cambrian microfossil and demonstration (with references to earlier published data of authors) of biotype of the same age, rich in microcosm in the zone of submarine volcanic eruptions. Obtained data are of great importance for explanation of the history of evolutionary development. That is why they are very important.

\section{Material and Methods}

Material for investigation comes from the Early Cambrian Karakatta Formation, the Terskoy-Alatau Range, northern Tien Shan. The sampled rocks include diabase, diabase porphyry, spilite, tuff, tuffite, jasper, and limestone lenses. A.G. Vologdin [2] found red algae Epiphyton cf. fruticosum Vologdin in the Karakatta Formation.

Red jasper specimens were studied by method, generally accepted in micropaleontology: they were cut into fine plates and transparent thin sections were prepared. They were studied in search of life remains in transmitted light using the microscope NU2 CARL ZEISS JENA (Germany). Micropaleontological material included well-preserved calcareous microfossils with a type of morphological structure characterized by various branching filaments.

\section{Results}

Detailed studies of Dolonophyton Kolosov, 1983 carried out by the authors showed that along with morphological features they preserved reproductive organs permitting their taxonomic position to be defined. Arguments are presented supporting the affinity of microfossils to major taxons of Rhodophyta. They were earlier referred to as paleontological remains with undefined taxonomic position (incertae sedis) [3].

Divisio Rhodophyta Pascher.

Classis Florideophyceae Lamour.

Genus Dolonophyton Kolosov, 1983, emend.

Dolonophyton: [3].

Typespecies—D. jaspideus Kolosov, 1983; Lower Cambrian, Karakatta Formation; western Karakatta Range, northern Tien Shan.

Diagnosis. Thallus filiform, consists of very small cells more or less rounded in section, compact (with no cavity inside), monopodially branched. Reproductive organs are tetraspores located at the surface of the thallus.

Species composition. Type species.

Remarks. In the systematics of recent Rhodophyta, the place of tetraspores formation is used as the main character of different groups. It is known that they occupy positions of end cells of the limited growth branches, ... intercalary origin of tetrasporangia, i.e. in the middle of cellular filaments, is extremely rare [4]. We observe well-preserved reproductive organs in microfossils found in red jasper rocks from the Karakatta Formation (Figures 1(b)-(d)). They are dispersed throughout the thallus surface. By the method of cell division they may be taken for cruciformly dividing tetrasporangia of the class Florideophyceae [5]-[7].

Tetraspores seem to be 4 in number in a cell. We look at the sporangium from the side and so can only distinguish 3 tetraspores (Figure 1(d)). First a cell is divided in two by a transverse septum and the formed two parts are further divided by two longitudinal septa oriented "at a right angle to one another" [4].

For Rhodophyta, the method of tetrasporangia division is considered to be the main character of a definite order. Except for most of Ceramiales, orders of the class Florideophyceae exhibit, in addition to zonal or tetrahedral, a cruciform division of sporangium [4]. The latter is characteristic of Nemaliales and Gelidiales. We observed tetrasporangia with a cruciform type of division located in the middle of a cellular filament in specimens of Rhodophyta that existed in the Early Cambrian at 535-513 Ma. Therefore, this type of tetrasporangia is the most primitive and the earliest in course of evolution of Rhodophyta. We consider the studied Early Cambrian calcareous forms to be representatives of the ancestors of recent Nemaliales, the most primitive group of Rhodophyta.

By analogy with some recent Rhodophyta in which tetrasporogenesis occurs at high temperatures (South, Whittick) one may assume that Dolonophyton jaspideus Kolosov lived in the same or close water environment. More accurate comparison of Rhodophyta, occurred over 500 million years ago, with recent ones is impossible. 


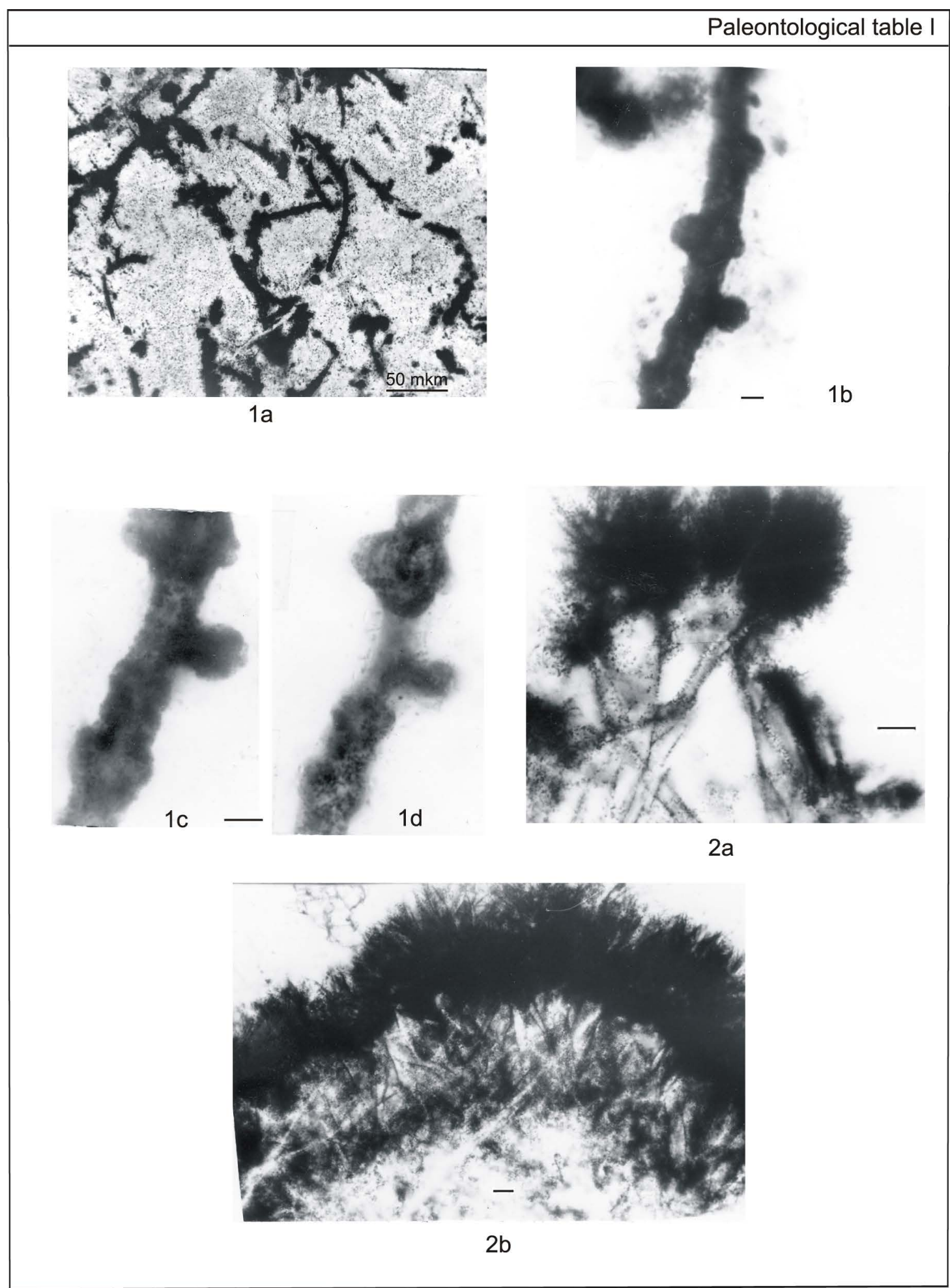

Figure 1. (Explanations to paleontological table I). Dolonophyton jaspideus Kolosov; holotype, IGABM SB RAS, no. 87-74, thin section no. 162-1, microscope stage coordinates 11.4: 136.8. (a) General view of a filiform thallus; holotype is shown by an arrow; (b) Fragment of thallus with several reproductive organs-tetraspores; (c) Well seen in the upper part of the figure are very small cells making up the thallus; (d) 3 (out of 4) tetraspores are observed in a crucuformly divided tetrasporangium. Renalcis granosus Vologdin, 1932: (a) General view; (b) Separate strongly branching filaments in the form of bushes. Scale $=10 \mathrm{mkm}$. 
Undoubtedly, recent Rhodophyta physiologically evolved for so long time, and they significantly differ from Pr for so long time for so long time Precambrian ones.

\subsection{Dolonophyton Jaspideus Kolosov, 1983}

Dolonophyton jaspideus: ([3], Figure 1, Figure 2(a) and Figure 2(b)).

Holotype-IGABM SB RAS, no. 87-77, thin section 162-1, microscopic (NU-2) stage coordinates (s.c.) 11.4; 136.8; northern Tien Shan; Lower Cambrian, Karakatta Formation.

Description. Thallus microscopic, calcified, length (measured) up to $430 \mu \mathrm{m}$, rarely up to $760 \mu \mathrm{m}$, width 8 $16 \mu \mathrm{m}$ more or less persistent over the whole length. Branching is weak. Very small $(1-2 \mu \mathrm{m})$ cells, more or less rounded in section, which make up the thallus, are indistinct (Figure 1, Figure 1(c), upper half). They are loosely packed. Tetraspores are numerous, spherical in shape, and have 8 - $9 \mu \mathrm{m}$ in diameter. They are located at the surface of the main axis of the plant (Figure 1, Figures 1(b)-(d)).

Material. A large amount (no less than 50) of well-preserved specimens in 5 transparent thin sections of red jaspers.

\subsection{Genus Renalcis Vologdin-Red Algae}

Now about calcareous microfossils widespread in Early Paleozoic rocks in many regions of the world (China, Australia, Canada, Morocco, etc.), which A.G. Volgdin described in 1932 as Renalcis Vologdin, 1932. Biology of these microfossils has not yet been interpreted. They are considered to be Cyanophyta by some paleoalgologists ([2], [8]-[11], and others), though there are no strong grounds for thinking so. Studies of microfossils found in the Karakatta Formation in the Lower Cambrian strata in northern Tien Shan (Figure 1) first showed that their morphology (filamentous, apically growing thallus in the form of strongly branching black bushes) is similar to that of red alga of the genus Polysiphonia Greville, 1824 ([12] [13], Figure 1) differing only in its microscopic size. From the above it may be assumed that the genus Renalcis Vologdin is an early representative of red algae rather than cyanobacteria.

\subsection{Paleobiocoenosis}

And finally about paleobiocoenosis in Karakattaian time at the sampling site in the Terskoy-Alatau Range, Tien Shan. Studies of samples collected in this area began in 1983. The presence there of spherulitic lavas and tuffs is clearly indicative of volcanogenic origin of red jaspers. Thin sections prepared from the specimens of these rocks contain microorganisms described earlier and in this paper. Paleobiocoenosis includes red algae Epiphyton sp., Renalcis granosus Vologdin, 1932, Dolonophyton jaspideus Kolosov, 1983 (Figure 1), Koroleviphyton attenuescens (Kolosov), 1983 (Figure 4), fungiform microorganisms Paleorhiphidium amplum Kolosov, 2013 (Figure 2, Figure 3) and conidia of aquatic fungi known as Karakattanella radiate Kolosov, 1983 [3] [14]-[16]. The mentioned biocoenosis indicates that 535-513 my ago a biotope rich in microorganisms developed on Earth in a shallow-water environment as a result of volcanic eruptions.

\section{Conclusions}

Definition of taxonomic position of Early Cambrian calcareous microfossils is not an easy matter. It is difficult to structurally and compositionally distinguish even between some recent microscopic Rhodophyta and Cyanophyta to say nothing of microorganisms that existed more than 500 Ma ago. However, comparison of morphological features and, what is more important, of preserved reproductive organs makes it possible, in some cases, to biologically interpret microfossils and define taxonomic position of ancient microorganisms. This approach in studying microfossils provides a better understanding of the early evolutionary stages of recent algae.

It is supposed that Precambrian red algae are mainly coccoid-type structures. The Early Cambrian was marked by a growing number of filamentous forms. Recent microscopic Rhodophyta (e.g. Asterocystis, Chroothece, Cyanidium etc.) are mainly represented by unicellular, more rarely colonial forms [17]. Contrastingly, among the Cambrian microscopic forms belonging to Rhodophyta there are a lot of organisms with a filamentous morphological structure characteristic of recent macroscopic Rhodophyta.

The results obtained provide additional support the presence in the Early Cambrian strata of Rhodophyta with a calcified thallus. As mentioned by B.I. Chuvashov [1], it is a peripheral part of the thallus that is more strongly 


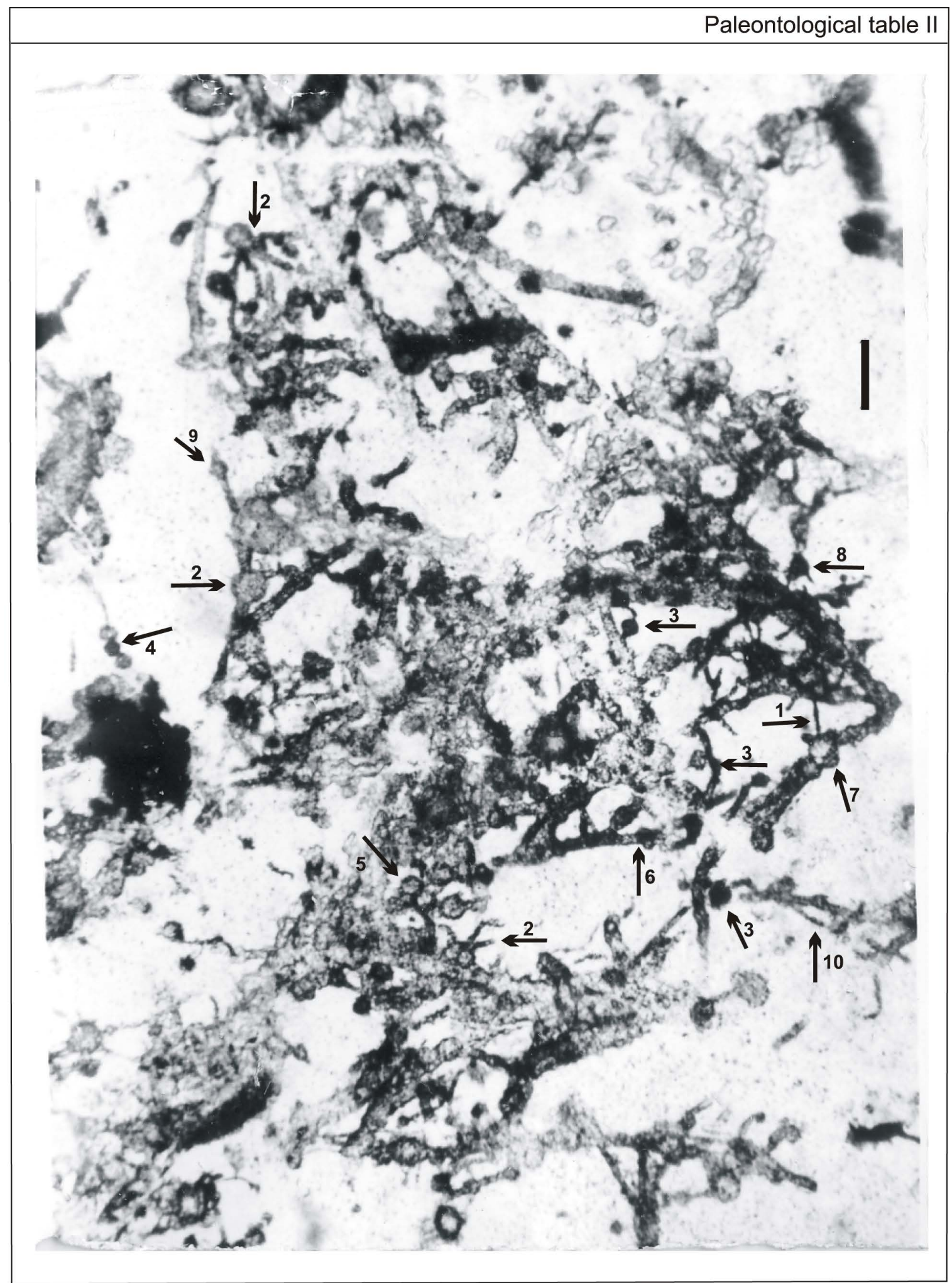

Figure 2. (Explanations to paleontological table II) 1-10. Palaeorhiphidium amplum gen. et sp. nov., specimen IGAMB SO RAN no. 87-141: (1) anastomoses; (2) zoosporangia with extending hyphae; (3) reproductive organs on sporangiophore; (4) conidia in chains; (5) cross-section of mycelia; (6) branching mycelium; (7)-(9) reproductive organs; (10) cellular hyphae (?). Scale bar 50 mkm (Kolosov, 2013, plate 14, p. 552). 


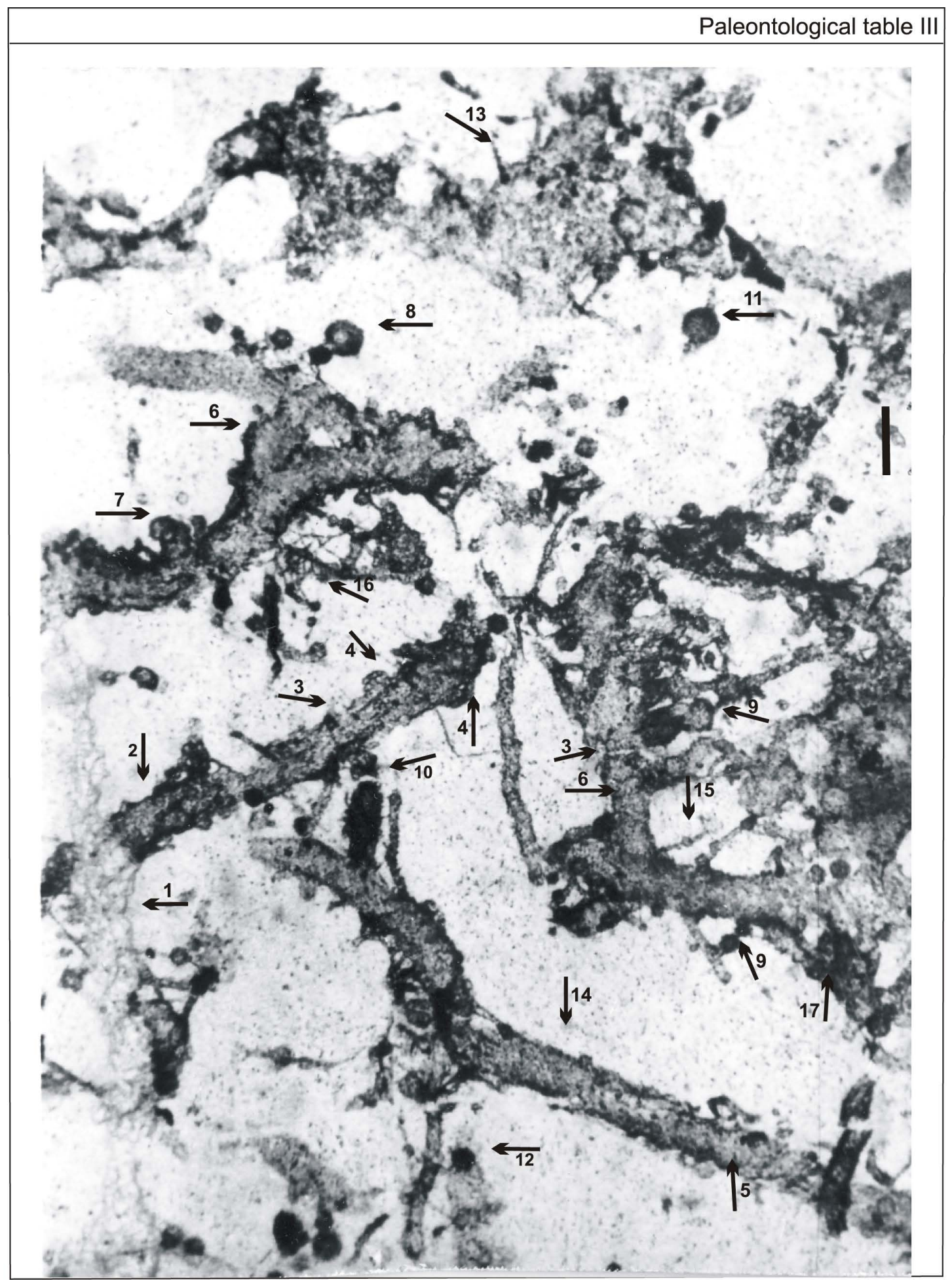

Figure 3. (Explanations to paleontological table III) 1-17. Palaeorhiphidium amplum gen. et sp. nov, holotype IGAMB SO RAN no. 87-140: (1) hyphae; (2) aerial mycelium composed of long thick hyphae; (3) septa (?); (4) wartlike reproductive organs; (5) mycelium with several presumed constrictions; (6) branches; (7) base of a lateral branch; (8-10) reproductive organs: (8) spheroidal, thick-walled, rising on sporangiophore, (9) spheroidal, small; (10) elongated, thick-walled, dark in thin sections; (11) biflagellate zoospores; (12) multiflagellate zoospores (?); (13) cellular (?) hyphae; (14) mycelium; (15) a spore (conidium or zoospore); (16) synnemae; (17) mycelium supposedly rising from the basal layer. Scale bar $50 \mathrm{mkm}$ (Kolosov, 2013, plate 13, pp. 550-551). 


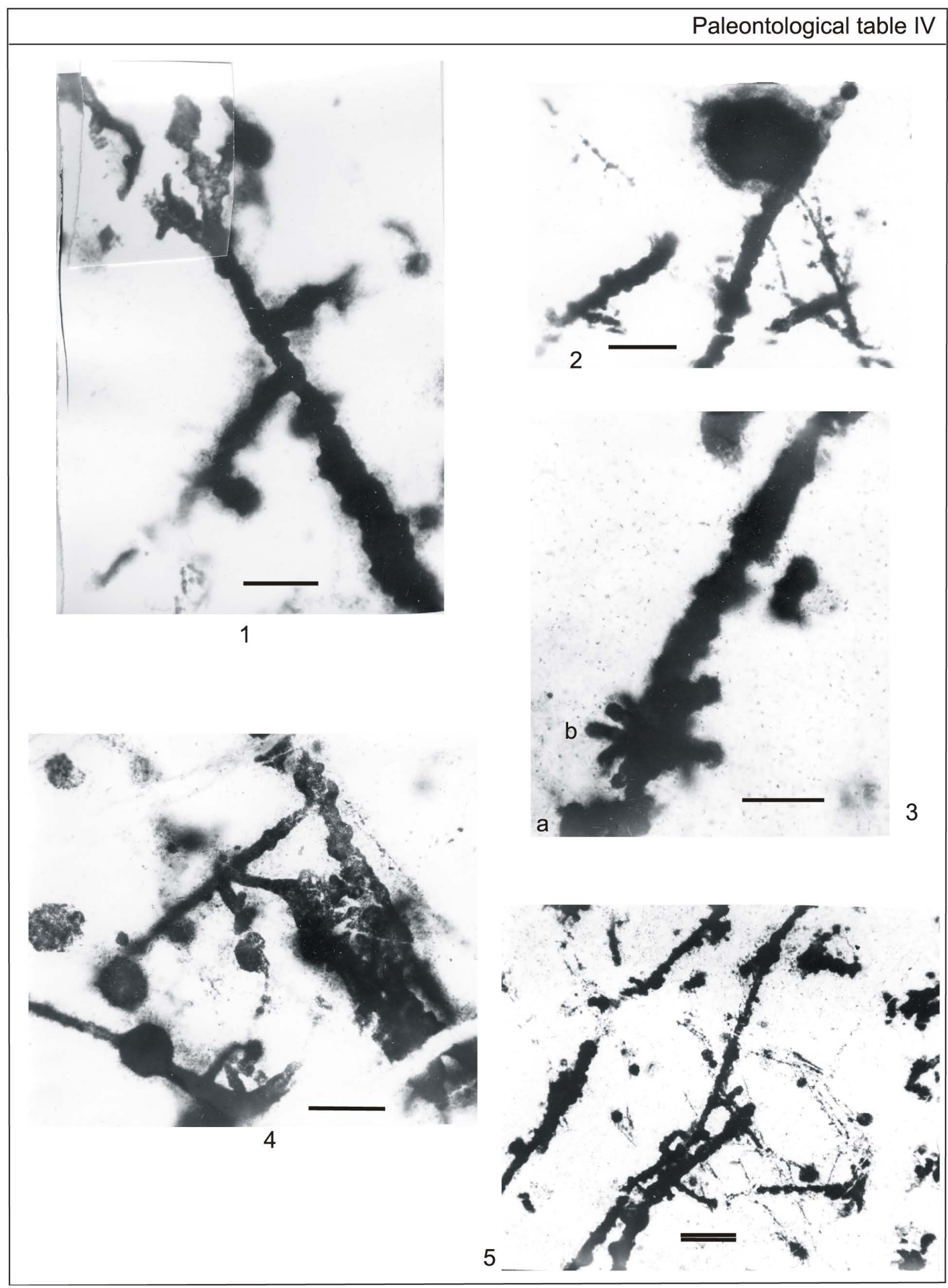

Figure 4. (Explanations to paleontological table IV). The single scale bar is $50 \mathrm{mkm}$ and double scale bar is $100 \mathrm{mkm}$. 1-5. Koroleviphyton attenuescens (Kolosov, 1983): (1) holotype DPMGI, no. 87-79-1, monopodially branching frond; (2) specimen DPMGI, no. 87-79-2: single spore; (3) specimen DPMGI, no. 87-79-3: basal cell with rhizoids: (3a) primary; (3b) secondary; (4) specimen DPMGI, no. 87-79-4, single spores on fronds; (5) specimen DPMGI, no. 87-79-5: fronds in longitudinal and cross sections (Kolosov, Sofroneeva, 2012, plate 18, pp. 430-431). 
fossilized by dark pelitomorphic calcium carbonate rather than cell walls. Due to this cells are almost indiscernible. This fossilization may be considered as characteristic of Cambrian Rhodophyta.

Well-preserved fossil remains found in the Early Cambrian rocks in the Terskoy-Alatau Range, northern Tien-Shan provide a vivid example of the appearance on earth at 535-513 Ma of morphologically complex fungiform microorganisms and red algae in a shallow-water biotope with favorable living conditions that resulted from manifestations of submarine volcanic eruptions. During this process, the water was saturated with various chemical elements and heated. The data presented in the paper increase our knowledge about an early (Cambrian) stage in the evolution of ecosystems and organic kingdom on Earth [18].

\section{References}

[1] (1987) Fossil Calcareous Algae (Morphology, Systematics, Methods of Study). Red Algae (Rhodophyta). Group of authors, Novosibirsk, 109-139.

[2] Vologdin, A.G. (1962) Ancient Algae of the USSR. Moscow, Izd-vo AN SSSR, 657 p.

[3] Kolosov, P.N., Maksumova, R.A., Korolev, V.G. and Konovod, A.V. (1983) A Record of Plant Microorganisms from the Lower Cambrian in the Karakatta Formation of Northern Tien Shan. Izvestia Akademii Nauk SSSR. Seriya Geologicheskaya, 3, 123-128.

[4] Gollerbakh, M.M. (1977) Life of Plants in Six Volumes. V.3: Algae. Lichens. Prosveshchenie, Moscow, 488 p.

[5] Zinova, A.D. (1967) Classifier of Green, Brown and Red Algae from Southern Seas of the USSR. Moscow-Leningrad, Nauka, 399 p.

[6] Vasser, S.P., Kondrat'eva, N.V., Masyuk, N.P., et al. (1989) Algae: A Reference Book. Kiev, Naukova Dumka, 608 p.

[7] South, R. and Whittick, A. (1990) Introduction to Phycology. Translated from English, Moscow, Mir, 597 p.

[8] Luchinina, V.A. (1975) Paleoalgological Characteristics of the Early Cambrian in the Siberian Platform. Novosibirsk, Nauka, 97 p.

[9] Korde, K.B. (1973) Cambrian Algae. Moscow, Nauka, 349 p.

[10] Wray, J.P. (1967) Upper Devonian Calcareous Algae from the Canning Basin, Western Australia. Colorado School of Mines, $49 \mathrm{p}$.

[11] Johnson, J.H. (1966) A Review of the Cambrian Algae. Quart, Colorado School of Mines, 61, 162 p.

[12] Scagel, R.F., Bandoni, R.J., Rouse, G.E., et al. (1967) An Evolutionary Survey of the Plant Kingdom. Belmont, Wadsworth, $658 \mathrm{p}$.

[13] Mukhin, V.A. and Tretyakova, A.S. (2013) Biological Diversity. Algae and Fungi. Rostov-on-Don, Phoenix, 269 p.

[14] Kolosov, P.N. and Sofroneeva, L.S. (2012) Calcareous Microfossils from the Karakatty Formation (Lower Cambrian) of the Northen Tien Shan. Paleontological Journal, 46, 430-432. http://dx.doi.org/10.1134/S0031030112030070

[15] Kolosov, P.N. (2013) Fungiform Organisms from the Early Cambrian of the Northern Tien Chan. Paleontological Journal, 47, 549-553. http://dx.doi.org/10.1134/S0031030113050080

[16] Sofroneeva, L.S. (2013) Biological Interpretation of Microfossils Karakattanella Kolosov from the Lower Cambrian of Northern Tien Shan. Nauka i Obrazovanie, 4, 50-53.

[17] Kondrat'eva, E.N., Maksimova, I.V. and Samuilov, V.D. (1989) Phototrophic Microorganisms: Textbook. Moscow, Izd-vo MGU, 376 p.

[18] Kolosov, P.N. (2013) The Role of Red Algae in Abrupt Appearance of Animals in the Early Cambrian on Siberian Platform. American Journal of Plant Sciences, 4, 60-64. http://dx.doi.org/10.4236/ajps.2013.412A2008 
Scientific Research Publishing (SCIRP) is one of the largest Open Access journal publishers. It is currently publishing more than 200 open access, online, peer-reviewed journals covering a wide range of academic disciplines. SCIRP serves the worldwide academic communities and contributes to the progress and application of science with its publication.

Other selected journals from SCIRP are listed as below. Submit your manuscript to us via either submit@scirp.org or Online Submission Portal.
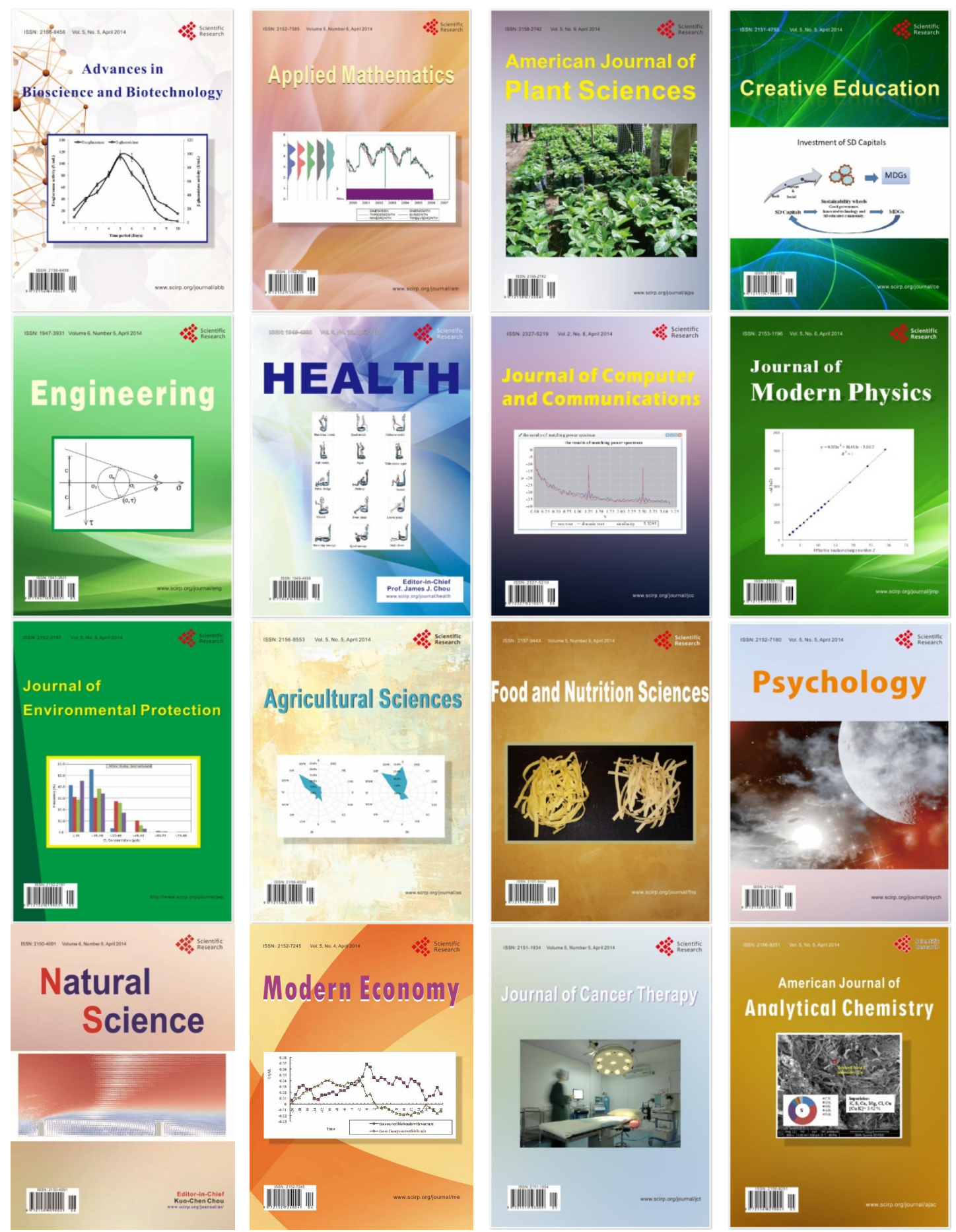